\section{EREM 76/3}

Journal of Environmental Research, Engineering and Management Vol. 76 / No.3 / 2020 pp. 137-153 DOI 10.5755/j01.erem.76.3.21928
Environmental Impact Assessment of Thai Minced Fish Paste (Surimi) Using Life Cycle Assessment Methodology

Accepted after revision 2020/08

\title{
Environmental Impact Assessment of Thai Minced Fish Paste (Surimi) Using Life Cycle Assessment Methodology
}

\section{Phairat Usubharatana, Harnpon Phungrassami*}

Excellence Centre of Eco-Energy, Chemical Engineering Department, Thammasat School of Engineering, Thammasat University, Pathumthani, Thailand

\section{*Corresponding author: pharnpon@engr.tu.ac.th}

Environmental impacts of fishery production have resulted in increased concern and awareness. Thailand, as one of the largest global fish exporters, faces challenges related to environmental problems caused by fishery processes. Here, the environmental impact of Thai surimi production was estimated based on life cycle assessment (LCA) methodology, focusing specifically on two Thai surimi products made from goatfish and ponyfish caught within the southern region of Thailand. Three impact categories where explored: global warming, acidification and eutrophication. Life cycle impacts were calculated for one $\mathrm{kg}$ of product using both mass and economic allocations. Results of this study indicated that goatfish has lower impacts than ponyfish for all the impact categories. Fuel consumption during the fishery phase and electricity consumption during processing were the main parameters leading to most of the considered environmental impacts. The value of Global Warming Potential(GWP) ranged within $1.3-3.0 \mathrm{~kg} \mathrm{CO}_{2}$ eq for goatfish and $2.2-7.1 \mathrm{~kg} \mathrm{CO}$ eq ponyfish depending on the allocation method. The acidification impact of goatfish and ponyfish were revealed at $3.2-7.3 \mathrm{gSO}_{2}$ eq and 12.7-39.7 $\mathrm{gSO}_{2} \mathrm{eq}$, respectively. The eutrophication of goatfish and ponyfish were 0.7-1.6 $\mathrm{gPO}_{4} \mathrm{eq}$ and 2.5-8.1 $\mathrm{gPO}_{4}$ eq, respectively. Sensitivity analysis of fuel consumption, electricity consumption, product yield and allocation method were evaluated.

Keywords: fishery, global warming, life cycle assessment, surimi. 


\section{Introduction}

The food industry is fundamental to the Thai economy with abundant resources delivering huge revenues to the nation in terms of foreign exchange exports. In 2016, the Thai fishery industry recorded a captured production of 1.5 million tonnes and was ranked $14^{\text {th }}$ with $2 \%$ of the worldwide gross. Moreover, Thailand was also ranked no. 4 among fishery exporters with a total value of 6 billion USD after China, Norway and Vietnam (FAO, 2016), emphasizing its position as a leading fishery exporting country.

There are approximately 1,300 fish processing plants throughout Thailand including freezing plants, canning plants, fish disposed of in sauce, steaming, smoking, salted fish, dried shrimp, dried squid and dried shellfish (Department of Fisheries, 2016). Total catches of marine and freshwater fish in 2016 were 1.08 and 0.57 million tonnes, respectively (Department of Fisheries, 2016). The fish processing industry is well known for high water consumption (Ferraciolli et al., 2017) and use of a wide variety of resources including fuel and electricity, which result in environmental impacts. In addition, following regulations for pollution control and environmental awareness by fish processing plants will reduce impact on the environment. Hospido et al. (2006) assessed the environmental impact of canned tuna production to identify the most significant contributor and improve the production process, while Thrane et al. (2009) focused on cleaner production in the fish processing industry. Results indicated significant environmental impacts related to the life cycle stages after landing the fish, including processing, transport, cooling and packaging. Morrissey and Tan (2000) claimed that surimi processing was responsible for a massive scale for wastewater and solid wastes pollution. Both direct and indirect impacts of fishing operation, including extraction, transformation of natural materials and fossil fuels, are considered as environmental inventory (Avadi and Freon, 2013).

These negative impacts caused by fisheries have increased environmental awareness among consumers (Arvanitoyannis and Kassaveti, 2008). Entrepreneurs, therefore, have to set the highest priority to realize solutions for these pollution aspects using effective tools such as life cycle assessment (LCA) to competently address the problem (Henriksson, 2012). Moreover, LCA can be used as a support tool for policy-makers and used for benchmarking (Irabarren et al., 2010). LCA was applied to quantify the environmental impacts of seafood production systems by Ziegler et al. (2016). This methodology could provide a comprehensive evaluation of the environmental implications of fisheries management (Hornborg et al., 2012).

LCA is now increasingly applied to analyze greenhouse gas emissions associated with the seafood supply chain (Pelletier and Tyedmers, 2008; Thrane, 2009; Parker, 2012). The greenhouse gas emission from fisheries is an important issue due to Cancun Agreements Mexico in 1992, the Kyoto protocol in 2005 (Hyun-young et al., 2017) and the Paris Climate Change Accord in 2015 (Jaehyun et al., 2019). It was estimated that the greenhouse gas emissions from fisheries constitutes around $2.5 \%$ of global emission (Garnett, 2011). Therefore, this study focused on environmental impacts, especially greenhouse gas emissions of the processed seafood derived from surimi production in Thailand at around 90,000 tonnes per year and considered as the highest quality in Southeast Asia (Guenneugues and lanelli, 2014). Surimi is a Japanese word meaning a fillet which is cleaned and dehydrated while maintaining the existing protein and subsequently converted to other products (Arvanitoyannis and Kassaveti, 2008; Shaviklo and Rafipour, 2013), such as kamaboko, chikuwa, fish sausages and fish balls (Kaewudom, 2013). Despite an increasing number of LCA case studies related to fisheries and aquaculture products, including Avadi and Freon (2013), the focus has been limited to the study of specific species such as Atlantic cod, Atlantic salmon and rainbow trout (Parker, 2012) or mackerel (Iribarren et al., 2011; Vazques-Rowa et al., 2010). Moreover, most LCA fishery studies were conducted in the Northeast Atlantic (Thrane, 2006; Vazques-Rowa et al., 2010) or Eastern Central Atlantic (Vazques-Rowa et al., 2012). Most of them summarized that fishing operation was the main environmental impact, especially fuel production, transportation and consumption of the fishing. To reduce fuel intensity, some 
authors recommended changing the type of fishing gear (Thrane, 2006). Later, Laso et al. (2018) evaluated global warming potential of anchovy fishing in northern Spain. Results indicated that the production, transportation and use of diesel were the main environmental hotspots, especially in relation to the global warming impact. One interesting result was studied by Ziegler et al. (2018). They analyzed the variability in environmental impacts of cod, haddock, saithe and shrimp in the Norwegian Sea. The crucial result was that no significant difference was observed in fuel use between years, but variability was within a year due to a difference catch rate. Although many researchers studied on the environmental impacts of fishery using LCA, none demonstrate thorough research concerning LCA or emission of greenhouse gases with regard to surimi production in Southeast Asia.

Therefore, here, goatfish and ponyfish as fish used for processing into surimi were evaluated using LCA methodology, focusing on the estimation of environmental impacts per $\mathrm{kg}$ of surimi, identification of hotspots in the surimi production chain and a sensitivity analysis to determine possible diverse variation parameters which potentially deliver high impact on the overall results.

\section{Methods}

LCA is a tool used to assess the environmental impacts of a specific product by considering the amount of resources consumed and the emissions to the receiving environment at all stages of its life cycle (Guinee et al., 2001). Evaluation is based on a systematic way to study the likely environmental impacts of a product or a service from cradle to grave (Reckmann et al., 2012). According to ISO standards, IS014040, LCA study has four phases as (1) goal and scope definition, (2) life cycle inventory analysis, (3) life cycle impact assessment and (4) interpretation (ISO, 2006). Here, an attributional LCA approach was applied, focusing on analysis of the environmental impacts from a product, a process or a system (Rehl et al., 2012).

\section{Goal and scope definitions}

The first phase of LCA is to define the goal and scope of the study. These include an objective, a functional unit and a system boundary of work to be performed. The objectives of this study were to 1) collect inventory data of Thai surimi and 2) understand and evaluate environmental emissions of Thai surimi production caused by different elements throughout the process. These two objectives were achieved using LCA methodology. Analyses focused on estimating the cradle to gate life cycle contributions to global warming, acidification and eutrophication. Two types of surimi were investigated, namely goatfish and ponyfish. Emissions from each were compared based on the different processing plants. Hotspot identification of surimi processing areas was also discussed. Results are intended for use by fishing companies and seafood industries using surimi as a raw material as well as LCA practitioners and other interested organisations or individuals.

According to International Standard 14040 (ISO, 2006), the functional unit is the quantified performance of a product system for use as a reference unit in an LCA study and provides the basis on which alternative products or processes can be compared and analysed (Rebitzer et al., 2004). All the environmental indicators are calculated on the basis of a single functional unit (Aubin et al., 2009). Fisheries managers may be interested in the impacts per live tonne of fish landed, while seafood retailers may be more interested in the impacts of packaged sale ready fillets (Parker, 2012). Moreover, the functional unit can also be assessed in terms of per mass, while others may prefer in per protein or per energy (Parker and Tyedmers, 2012). The most common functional unit for fishery case studies was a given mass of fillets (Parker, 2012). Therefore, the functional unit based on the interested impact and goal of this study was set at $1 \mathrm{~kg}$ of surimi.

The allocation method is a common discussion aspect. Many researchers, especially regarding aquaculture, applied an economic based allocation (Iribarren et al., 2011; Ziegler et al., 2011), while others interested in fisheries mostly applied a mass based allocation (Ellingsen and Aanondsen, 2006; Vazques-Rowe et al., 2010; Vazques-Rowe et al., 2012). IS014040 series (ISO, 2006) recommends avoiding allocation by splitting the processes or system expansion; however, splitting the processes is not possible for the fishing phase because the fish are caught in similar places 
with the same equipment (Svanes et al., 2011). System expansion was not attempted due to the lack of data. In cases where allocation cannot be avoided, the environmental burdens of the system should be allocated according to an underlying physical relationship (Ayer et al., 2007). Following Svanes et al. (2011), two main output processes were included in this study: 1) fishery, yielding many different fish species and 2) surimi processing, yielding product and by-products. Therefore, allocation of fishery process was applied by mass where more than one species were captured simultaneously during fishing operations (Vazques-Rowe et al., 2010). Allocation of Thai surimi processing was applied using both mass and economics where solid fish wastes, regarded as by-products, were intercepted and used as raw materials for animal feed production. Mass and economic allocation factors for two products of Thai surimi are shown in Table 1. Economic value was based on year 2012-2013 when data were collected. Scenario 1 (S1) was specified as fishing and surimi-producing operations using mass allocation in both processes, and scenario 2 (S2) was specified for fishing operations applied with mass allocation under producing processes with economic based allocation.

Table 1. Mass and economic allocation factors (raw data)

\section{Fish (tonne)}

Fishery process

Goatfish

\begin{tabular}{|c|c|c|c|c|}
\hline Goatfish & 6.68 & $37 \%$ & - & - \\
\hline Other species & 11.33 & $63 \%$ & - & - \\
\hline \multicolumn{5}{|l|}{ Ponyfish } \\
\hline Ponyfish & 433.24 & $3 \%$ & - & - \\
\hline Other species & 15.171 .36 & $97 \%$ & - & - \\
\hline \multicolumn{5}{|c|}{ Surimi process } \\
\hline \multicolumn{5}{|l|}{ Goatfish } \\
\hline Goatfish & 1.517 .38 & $40 \%$ & 2.00 & $90 \%$ \\
\hline Other species & 2.276 .08 & $60 \%$ & 0.15 & $10 \%$ \\
\hline \multicolumn{5}{|l|}{ Ponyfish } \\
\hline Ponyfish & 122.22 & $28 \%$ & 2.92 & $90 \%$ \\
\hline Other species & 311.02 & $72 \%$ & 0.12 & $10 \%$ \\
\hline
\end{tabular}

\section{Life cycle inventory}

Life cycle inventory $(\mathrm{LCl})$ is the second phase of an LCA study. This study constitutes a partial LCA from cradle to gate. Goatfish and ponyfish vary widely in sourcing localities around the Gulf of Thailand. Goatfish landed in Thailand, India, Vietnam and Indonesia at larger size (100-200 g) is sold throughout European markets, while smaller sized fish is processed into surimi (Guenneugues and lanelli, 2014). The boundary encompasses all major fishery activities required to catch and deliver fish to the dockside in Southern Thailand.
Data regarding goatfish catches were acquired from collective interviews with fishermen based on nine fishing excursions. They sold fish at the market to a surimi manufacturer. Information on ponyfish fishing activities was obtained directly from surimi manufacturers who operated their own fishing boats. Data were averaged and computed based on annual records, focusing on the main parameters such as the amount of diesel and ice cubes used during fishing activities and fish transportation to the dock. Surimi manufacturers then buy the fish if they have no stocks 
and take them to the manufacturing plant, assumed to be $5 \mathrm{~km}$ away.

The surimi production process is shown in Fig. 1 and comprises the following: (1) material receipt, washing, de-heading and gutting processes; (2) fish cleaning in cold water and ice to maintain fish temperature and retain the freshest quality; (3) fish classification to debone and produce fish fillets (using too much strength during this process may cause dull colour of the fillets as colours of the internal organs may stick to them); (4) surimi cleaning and leaching to eliminate undesired protein, fat, blood and other contaminants or grinding the fish meat using $20-30 \%$ concentrated saline water; (5) dehydration of the fish meat using a hydraulic filter press; (6) removal of dish scales, skin and bone (the surimi is passed through a refiner with a high-speed centrifuge to separate the soft white fish meat using a fine sieve); (7) packing and freezing (the refined minced fish meat is packed in polyethylene-plastic bags and stored in freezers at $-20^{\circ} \mathrm{C}$ ). Fish waste is processed into animal food, priced as in Table 1.

Fig. 1. Surimi processing

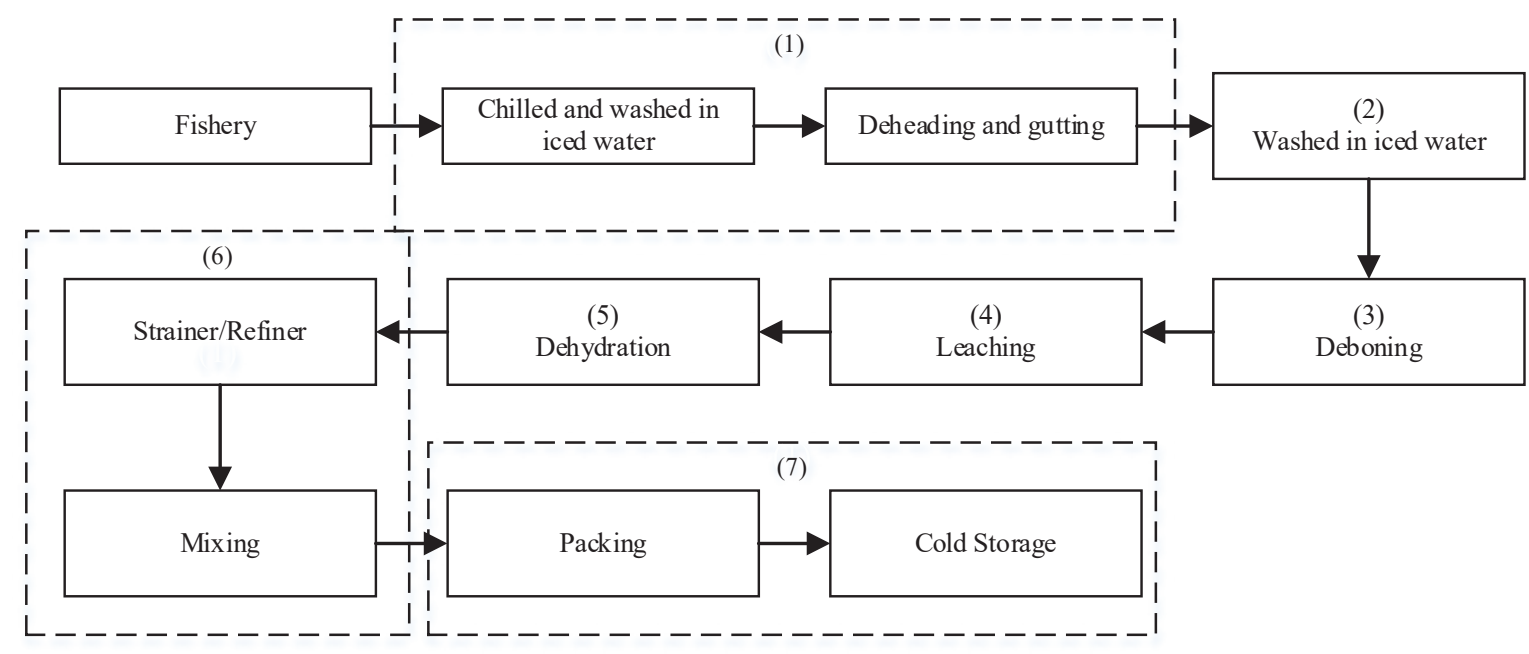

\section{Impact assessment}

After collection in the life cycle inventory phase, consumption and emission data were calculated for each of the environmental impact categories. Analysis focused on the life cycle contributions to the global warming potential (GWP), acidification potential (AP) and eutrophication potential (EP). These three potentials were measured in carbon dioxide equivalent or $\mathrm{CO}_{2}$ eq, sulphur dioxide equivalent or $\mathrm{SO}_{2}$ eq and phosphate equivalent or $\mathrm{PO}_{4}$ eq, respectively. The method used for environmental characterization followed CML2001 (Guinee et al., 2001) as the most common characterization model (Parker, 2012).
Emissions associated with production of Thai surimi were quantified as:

$$
E_{x}=\sum_{i=1}^{n}\left(A_{i} \times E F_{x, i}\right)
$$

Where: $\mathrm{E}_{\mathrm{x}}$ is environmental impact $\mathrm{x}$ (index for impact category: global warming, acidification, eutrophication); $A_{i}$ is activity data in the fisheries and surimi processing as shown in Tables 2 and 3; $E F_{x, i}$ is the emission factor for $\mathrm{x}$ impact category due to activity $\mathrm{i}$ in each process. 


\section{Results and Discussion}

\section{Life cycle inventory ( $(\mathrm{Cl})$}

Results from the $\mathrm{LCl}$ study are summarised in Tables 2 and 3 as activity data and sources. Inventory data were divided into two subsystems: fishery activities and surimi processing. Fishery activities included fish catching, ice processing and fuel oil. The painting process as maintenance was not included due to the lack of data. Ziegler et al. (2003) maintained that the painting process was negligible with a very low contribution to environmental impacts. Surimi processing activities as previously discussed offer interesting energy consumption in both the fishery and processing phases. For energy consumption, only direct electricity and direct energy uses were taken into account. According to Fig. 2, diesel consumption during fish catching and electricity use during surimi processing were the highest values. By contrast, values during fish transportation from dock to factory were the lowest. During fish catching, $1 \mathrm{~kg}$ of goatfish used $1.12 \times 10^{-4}$ tonne oil equivalent (TOE) (S1) and $2.51 \times 10^{-4}$ TOE (S2), equal to $48 \%$ of the total life cycle energy used. In terms of the manufacturing process, goatfish

Table 2. Inputs and outputs of the goatfish surimi supply chain

\begin{tabular}{|c|c|c|c|}
\hline Phase & Parameter & Value & Data sources \\
\hline \multirow{7}{*}{ Fishery } & Fuel consumption & $1.082 \times 10^{-1} \mathrm{~kg}$ of diesel per $\mathrm{kg}$ caught fish & * \\
\hline & Ice & $4.864 \times 10^{-2} \mathrm{~kg}$ per $\mathrm{kg}$ caught fish & * \\
\hline & Electricity & $8.848 \times 10^{-3} \mathrm{kWh}$ per $\mathrm{kg}$ ice & * \\
\hline & Ammonia & $2.807 \times 10^{-5} \mathrm{~kg}$ per $\mathrm{kg}$ ice & * \\
\hline & Sodium chloride & $5.603 \times 10^{-4} \mathrm{~kg}$ per $\mathrm{kg}$ ice & * \\
\hline & Paint & Not available data & $\star \star *$ \\
\hline & Catch 4 main species & $\begin{array}{l}\text { Threadfin Bream; 25\%, Lizard; 30\%, Goatfish; 37\%, and } \\
\text { others; } 8 \%\end{array}$ & * \\
\hline \multirow{9}{*}{$\begin{array}{l}\text { Surimi } \\
\text { processing }\end{array}$} & Processing yield & Surimi; 40\%, by product; 60\% & $* * *$ \\
\hline & Transportation of goatfish & $3.224 \times 10^{-3} \mathrm{tkm}$ per kg surimi & 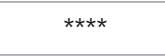 \\
\hline & Electricity & 1.974 kWh per kg surimi & $* * *$ \\
\hline & Ice & 2.141 kg per kg surimi & $* * *$ \\
\hline & Sugar & $5.600 \times 10^{-2} \mathrm{~kg}$ per $\mathrm{kg}$ surimi & $* * *$ \\
\hline & Chemical consumption & $\begin{array}{l}\text { All in } \mathrm{kg} \text { of surimi } \\
\text { Phosphate; } 2.200 \times 10^{-3} \mathrm{~kg} \text {, Acetic acid } 1.000 \times 10^{-4} \mathrm{~kg} \text {, } \\
\text { Salt; } 2.900 \times 10^{-3} \mathrm{~kg} \text {, Chlorine; } 1.000 \times 10^{-4} \mathrm{~kg} \text {, } \\
\text { Ammonia; } 1.000 \times 10^{-4} \mathrm{~kg}, \mathrm{CaCO}_{3} ; 5.000 \times 10^{-4} \mathrm{~kg} \\
\text { Sodium hypochlorite; } 7.300 \times 10^{-3} \mathrm{~kg}\end{array}$ & $* \star \star$ \\
\hline & Water & $5.000 \times 10^{-2} \mathrm{~m}^{3}$ per kg surimi & $* \star \star$ \\
\hline & Wastewater & $5.060 \times 10^{-2} \mathrm{~m}^{3}$ per kg surimi & $* * *$ \\
\hline & $\begin{array}{l}\text { Utility: wastewater } \\
\text { treatment }\end{array}$ & Electricity; 5.074 kWh per $\mathrm{m}^{3}$ treated wastewater & $* * *$ \\
\hline
\end{tabular}

\footnotetext{
* Fishing company with catch records; average from nine fishing excursions (primary data of this present research)

** Presumed to be negligible according to LCA results of Ziegler et al. (31)

${ }^{* * *}$ Average from 1 year collected data from a surimi processing company (primary data of this present research)

${ }^{* * * *}$ Distance collected from a surimi processing company (primary data of this present research)
} 
Table 3. Inputs and outputs of the ponyfish surimi supply chain

\begin{tabular}{|c|c|c|c|}
\hline Phase & Parameter & Value & Data sources \\
\hline \multirow{7}{*}{ Fishery } & Fuel consumption & $5.547 \times 10^{-1} \mathrm{~kg}$ of diesel per $\mathrm{kg}$ caught fish & * \\
\hline & Ice & $9.017 \times 10^{-3} \mathrm{~kg}$ per $\mathrm{kg}$ caught fish & * \\
\hline & Electricity & $7.951 \times 10^{-3} \mathrm{kWh}$ per $\mathrm{kg}$ ice & * \\
\hline & Sodium chloride & $4.274 \times 10^{-4} \mathrm{~kg}$ per $\mathrm{kg}$ ice & * \\
\hline & $\mathrm{NaOCl}$ & $6.480 \times 10^{-5} \mathrm{~kg}$ per $\mathrm{kg}$ ice & * \\
\hline & Paint & No available data & ** \\
\hline & Catch & Ponyfish; 3\%, others; 97\% & * \\
\hline \multirow{10}{*}{$\begin{array}{l}\text { Surimi } \\
\text { processing }\end{array}$} & Processing yield & Surimi; 28\%, by-products; 72\% & * \\
\hline & Transportation of ponyfish & $1.772 \times 10^{-2} \mathrm{tkm}$ per kg surimi & $* * *$ \\
\hline & Electricity & $9.343 \times 10^{-2} \mathrm{kWh}$ per $\mathrm{kg}$ surimi & * \\
\hline & Ice & $2.184 \times 10^{-2} \mathrm{~kg}$ per kg surimi & * \\
\hline & Chemical consumption & Ammonia; $4.664 \times 10^{-4} \mathrm{~kg}$ per $\mathrm{kg}$ surimi & * \\
\hline & Water & $4.860 \times 10^{-2} \mathrm{~m}^{3}$ per kg surimi & * \\
\hline & Wastewater & $4.862 \times 10^{-2} \mathrm{~m}^{3}$ per $\mathrm{kg}$ surimi & * \\
\hline & $\begin{array}{l}\text { Utility: cool water } \\
\text { processing }\end{array}$ & Electricity; 7.951 kWh per $\mathrm{m}^{3}$, Salt; $4.274 \times 10^{-1} \mathrm{~kg}$ per $\mathrm{m}^{3}$ & $* * *$ \\
\hline & water; $1.142 \mathrm{~m}^{3}$ per $\mathrm{m}^{3}$ & * & $* * *$ \\
\hline & $\begin{array}{l}\text { Utility: wastewater } \\
\text { treatment }\end{array}$ & Electricity; $6.789 \times 10^{-1} \mathrm{kWh}$ per $\mathrm{m}^{3}$ treated wastewater & * \\
\hline
\end{tabular}

${ }^{*}$ Average from 1 year collected data from a surimi processing company (primary data of this present research)

** Presumed to be negligible according to LCA results of Ziegler et al. (31)

${ }^{* * *}$ Distance collected from a surimi processing company (primary data of this present research)

surimi consumed $1.23 \times 10^{-4}$ TOE (S1) and $2.77 \times 10^{-4}$ TOE (S2), or $52 \%$ of the total life cycle energy used. For ponyfish surimi, fish catching consumed most energy or up to $5.75 \times 10^{-4}$ TOE (S1) and $1.84 \times 10^{-4} \mathrm{TOE}$ (S2) with diesel as the greatest contributor, equivalent to $98 \%$ of the total life cycle energy used. In other words, ponyfish surimi exerted 2.5 times more energy than goatfish surimi in scenario 1 and 3.5 times less in scenario 2 because goatfish can be caught close to the shore. However, most energy consumption during surimi processing resulted from electricity used in the freezing system, ice and cold water production as well as the freezing process. Results showed that 14 times less energy was required to produce ponyfish surimi than to produce goatfish surimi in scenario 1 and the figure was 10 times lower in scenario 2, equivalent to electricity consumption during processing at $1.90 \mathrm{kWh}$ per $\mathrm{kg}$ for goatfish surimi and $0.09 \mathrm{kWh}$ per $\mathrm{kg}$ for ponyfish surimi. This was because manufacturing of ponyfish surimi ran as a modern continuous process with sophisticated and efficient strategic procurement of raw materials whereas goatfish surimi manufacture relied on a batch process, causing system inconsistencies and requiring more energy. In addition, goatfish surimi entrepreneurs did not have their own fishing boats, which increased complications in process planning. 
Fig. 2. Energy use in life cycle per kilogram of surimi (unit: 10-9 TOE)

10000000

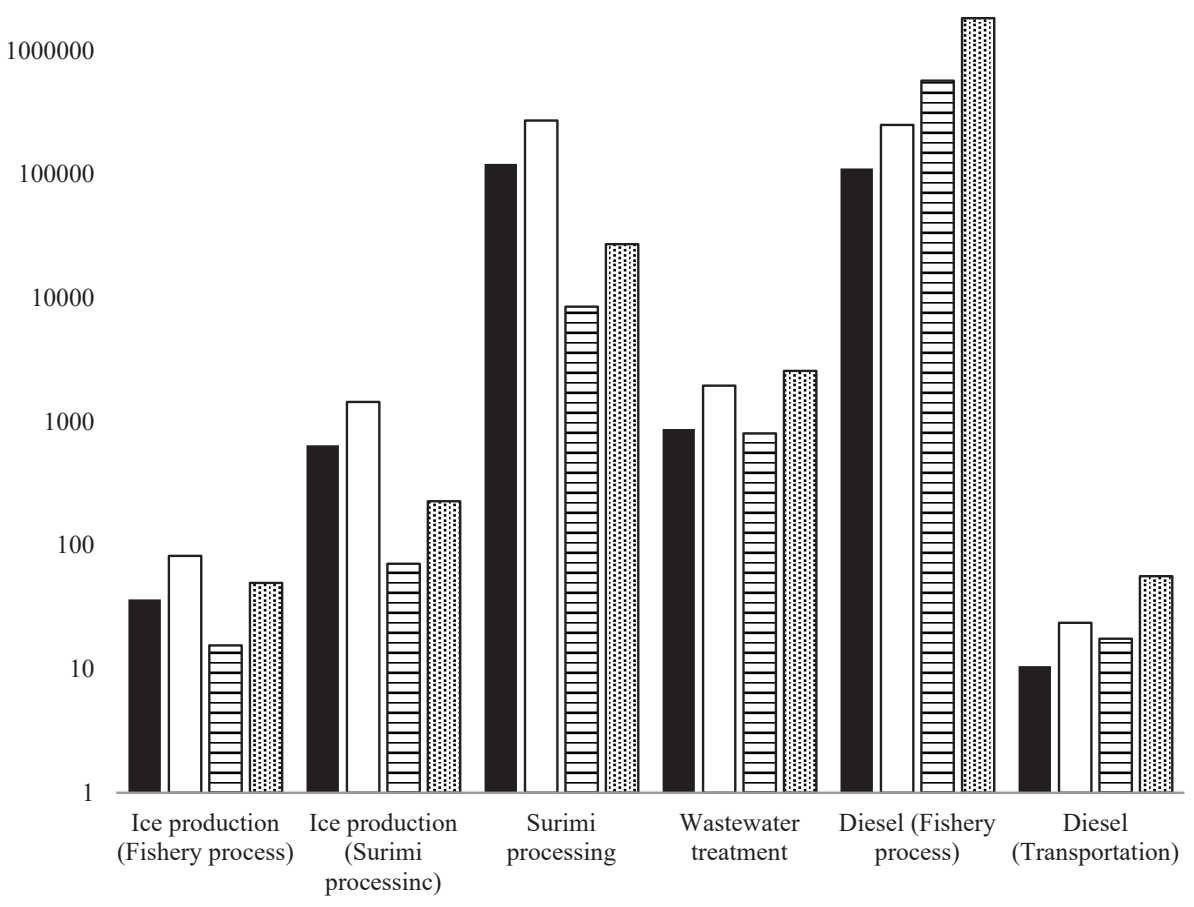

- Goatfish surimi: S1 口Goatfish surimi: S2 घPonyfish surimi: S1 §Ponyfish surimi: S2

\section{Life cycle impact assessment}

Three impacts were studied as global warming (GWP), acidification (AD) and eutrophication (EP). These factors are commonly assessed by LCA and widely used for aquatic product processing (Henriksson et al., 2012). Following the principle of environmental impact assessment, the acquired $\mathrm{LCl}$ values were computed and converted into scales of environmental impacts. CML2001 was used as the characterization model. The main results from LCA of the two products are summarized in Table 4. Tables 5 and 6 present emissions of selected pollutants in each impact category. Fish waste from surimi processing is sold as animal food; therefore, allocation is essential.

Table 4. Life cycle impact assessment results

\begin{tabular}{l|c|r|r|r|r}
\hline \multirow{2}{*}{} & \multicolumn{3}{|c|}{ Goatfish surimi } & \multicolumn{2}{c}{ Ponyfish surimi } \\
\cline { 2 - 6 } & \multicolumn{1}{|c|}{ Unit } & Scenario 1 & Scenario 2 & Scenario 1 & Scenario 2 \\
\hline Global warming & $\mathrm{g} \mathrm{CO}_{2} \mathrm{eq}$ & 1330.94 & 2983.15 & 7141.75 \\
\hline Acidification & $\mathrm{g} \mathrm{SO}_{2} \mathrm{eq}$ & 3.25 & 7.28 & 2230.60 & 12.62 \\
\hline Eutrophication & $\mathrm{g} \mathrm{PO}_{4} \mathrm{eq}$ & 0.73 & 1.64 & 2.55 & 8.10 \\
\hline
\end{tabular}




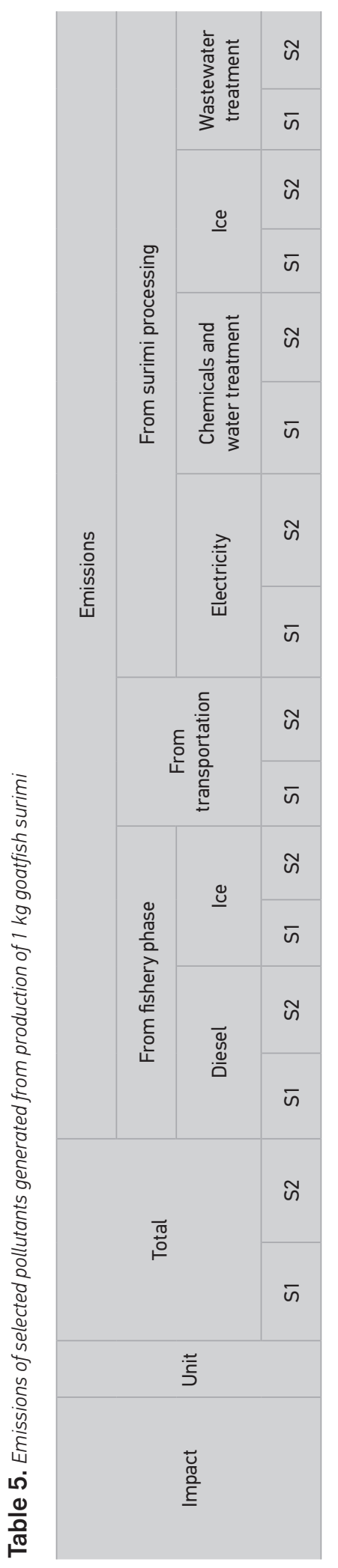

\begin{tabular}{|c|c|c|}
\hline$\stackrel{\text { }}{\stackrel{一}{ٍ}}$ & : & : \\
\hline ָુ & : & : \\
\hline 艿 & : & : \\
\hline 字 & : & : \\
\hline 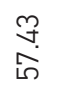 & $\overline{\bar{o}}$ & $\bar{o}$ \\
\hline 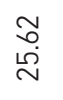 & 哭 & 잉 \\
\hline 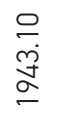 & $\frac{N}{0}$ & $\stackrel{\text { og }}{0}$ \\
\hline $\begin{array}{l}\text { 令 } \\
\text { ळ. }\end{array}$ & 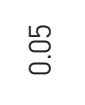 & ō \\
\hline og & : & : \\
\hline 売 & : & : \\
\hline : & : & : \\
\hline Ñ & : & : \\
\hline$\underset{\substack{\infty \\
\infty \\
\infty}}{\stackrel{\infty}{0}}$ & $\stackrel{\mathscr{n}}{=}$ & $\stackrel{m}{0}$ \\
\hline $\begin{array}{l}\text { 㝵 } \\
\text { 岁 }\end{array}$ & 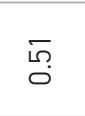 & 㐫 \\
\hline 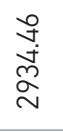 & $\stackrel{\widehat{m}}{\stackrel{p}{-}}$ & $\stackrel{\circ}{\circ}$ \\
\hline 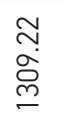 & ○. & $\stackrel{\text { og }}{0}$ \\
\hline or & $\sigma$ & or \\
\hline $8^{2}$ & $I^{s}$ & $\overbrace{z}^{\circ}$ \\
\hline
\end{tabular}

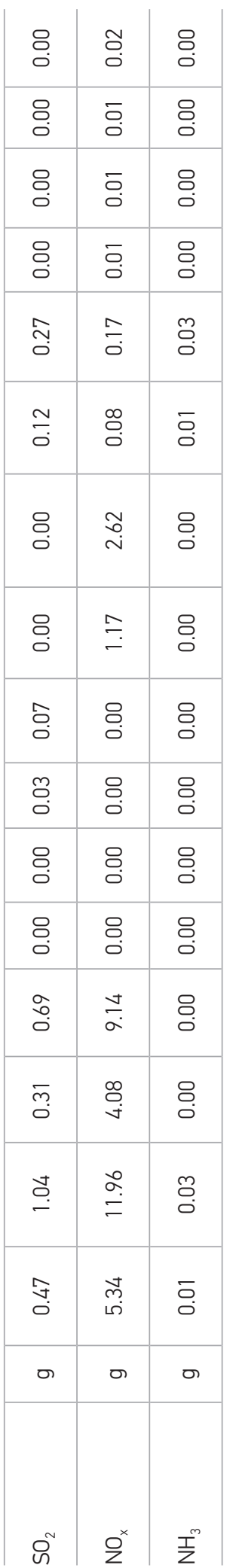

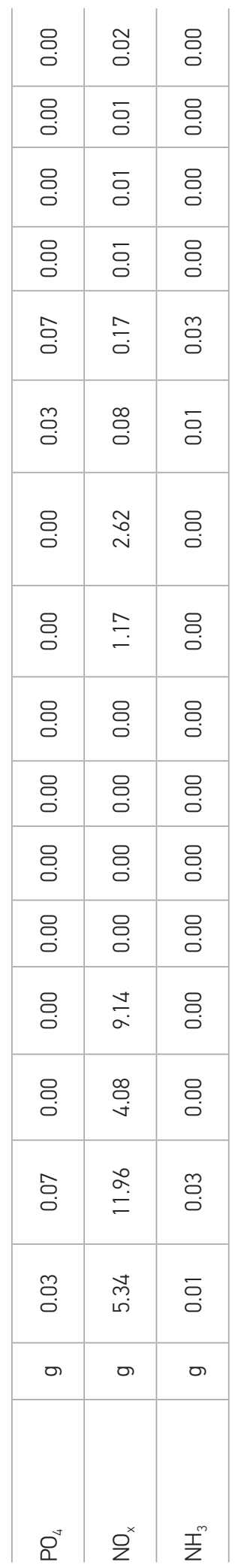




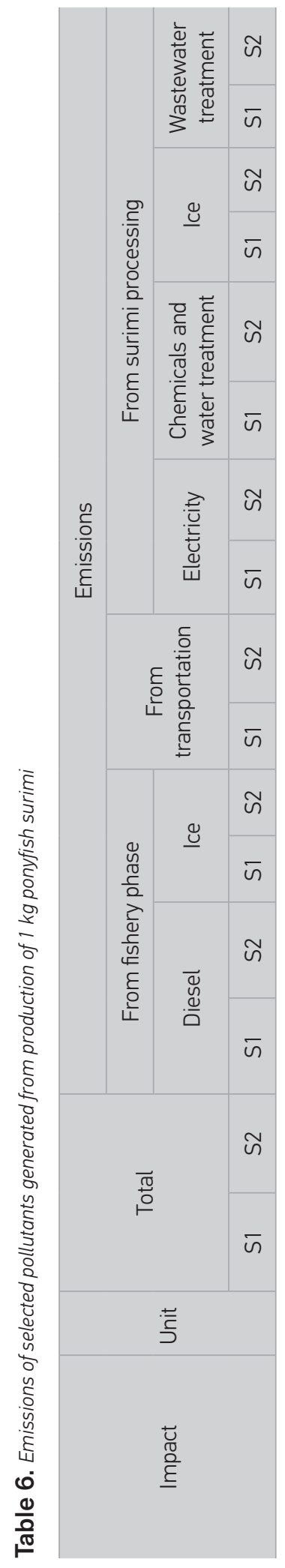

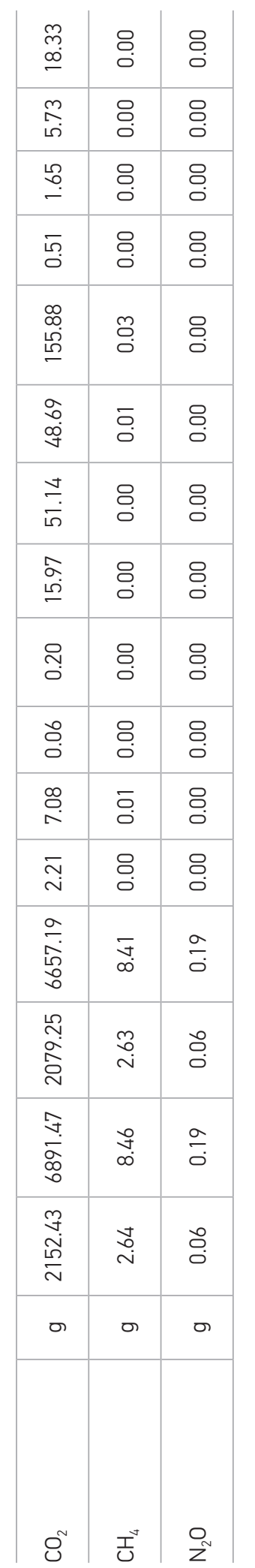

\begin{tabular}{|c|c|c|}
\hline 응. & ָ̊. & O. \\
\hline ㅇ. & ס. & O. \\
\hline 응 & 웅 & 8 \\
\hline 웅 & \&. & 8 \\
\hline ஜ̊. & $\underset{\sim}{\mathbb{N}}$ & 8 \\
\hline$\frac{\infty}{\sigma}$ & $\stackrel{\Xi}{0}$ & $\overline{0}$ \\
\hline 웅 & 웅. & 8 \\
\hline 응 & ָ̊ & 8. \\
\hline 응. & 용 & ㅇ. \\
\hline 品 & 品 & O. \\
\hline ס̊ & $\bar{\sigma}$ & 응 \\
\hline$\sigma_{0}$ & 웅 & ㅇ. \\
\hline o & $\begin{array}{l}0 \\
2 \\
0 \\
0\end{array}$ & 응 \\
\hline جִ & $\begin{array}{l}\bar{a} \\
\bar{\sigma}\end{array}$ & 응 \\
\hline$\frac{J}{ \pm !}$ & 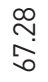 & 웅 \\
\hline$\stackrel{\infty}{\stackrel{\infty}{\sim}}$ & $\frac{\cong}{\stackrel{\varpi}{\sim}}$ & $\overline{0}$ \\
\hline or & $\sigma$ & or \\
\hline$\stackrel{n}{n}^{N}$ & $\frac{\mathrm{O}^{x}}{\mathrm{x}}$ & $\bar{\Sigma}^{m}$ \\
\hline
\end{tabular}

\begin{tabular}{|c|c|c|}
\hline 8 & ণ̊ & 앙 \\
\hline 응 & ס. & ㅇ. \\
\hline ㅇ. & 응 & 응 \\
\hline 응. & 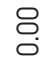 & 品 \\
\hline 응 & $\stackrel{\circ}{\circ}$ & O. \\
\hline $\bar{\sigma}$ & $\stackrel{\text { L }}{\sim}$ & $\bar{O}$ \\
\hline 응 & 웅. & 品 \\
\hline 응 & ָ̊. & 品 \\
\hline 응 & 응 & 응 \\
\hline 응 & 용. & 品 \\
\hline 응 & ס. & \&. \\
\hline 응 & 응. & 응. \\
\hline 뭉 & $\underset{\underset{N}{N}}{\stackrel{乛}{N}}$ & 앙 \\
\hline 응 & \begin{tabular}{l}
\multirow{J}{*}{} \\
$\stackrel{J}{-}$
\end{tabular} & 앙 \\
\hline 뭉 & $\begin{array}{l}\stackrel{0}{0} \\
\infty \\
0 \\
0\end{array}$ & 응 \\
\hline $\bar{\sigma}$ & $\frac{\approx}{\alpha}$ & $\bar{O}$ \\
\hline$\sigma$ & or & $\sigma$ \\
\hline$\AA^{+}$ & $\mathrm{O}^{x}$ & $\frac{T}{z}$ \\
\hline
\end{tabular}


Goatfish surimi possessed the global warming potential at $1.33 \mathrm{~kg} \mathrm{CO}_{2}$ eq per $\mathrm{kg}(\mathrm{S} 1)$ and $2.98 \mathrm{~kg} \mathrm{CO}_{2}$ eq per $\mathrm{kg}(\mathrm{S} 2)$. Change from mass allocation to economic allocation resulted in an increase of the global warming potential at up to $124 \%$ since the ratio for mass allocation was only $40 \%$ while that of economic allocation was $90 \%$. Similarly, acidification potential also increased from $3.25 \mathrm{~g} \mathrm{SO}_{2}$ eq per $\mathrm{kg}$ of goatfish surimi to $7.28 \mathrm{~g} \mathrm{SO}_{2}$ eq per $\mathrm{kg}$ of goatfish surimi with eutrophication up from $0.73 \mathrm{~g} \mathrm{PO}_{4}$ eq per $\mathrm{kg}$ of goatfish surimi to $1.64 \mathrm{~g} \mathrm{PO}_{4}$ eq per $\mathrm{kg}$ of goatfish surimi. For ponyfish surimi, change of mode from mass allocation at $28 \%$ to economic allocation at $90 \%$ resulted in an increase of all three impact categories similar to goatfish surimi. Results after altering allocation methods were variable, depending on prices and proportions of the acquired yield. For ponyfish surimi as very small fish, yields were low. Using mass allocation, impacts are allotted to a waste rather than a product and the price of a product is much more than that of a waste when based only on economic allocation as shown in Table
1. Results concurred with Svanes et al. (2011a) and Svanes et al. (2011b) who determined increased environmental impacts as a result of economic allocation. Ayer et al. (2007) pointed out that economic allocation consistently varied and did not reflect actual flows of energies and materials.

Figs. 3-4 show percentage contributions of 6 processes and activities to potential environmental impacts. Table 5 and Fig. 3 show electricity used in goatfish surimi processing as an important source of pollutants and environmental impacts at $65 \%$ of the global warming potential with $18 \%$ from acidification and $21 \%$ from eutrophication. In the fishery process, contribution percentages of global warming, acidification and eutrophication were $32 \%, 74 \%$ and $73 \%$, respectively. The major parameter during fish catching was the consumption of diesel, which concurred with research by Vazques-Rowe et al. (2010) and Ziegler et al. (2016). Ice production and wastewater treatment processes presented very low percentages, ranging within $0.1-0.5 \%$.

Fig. 3. Contribution of different phases of goatfish surimi production

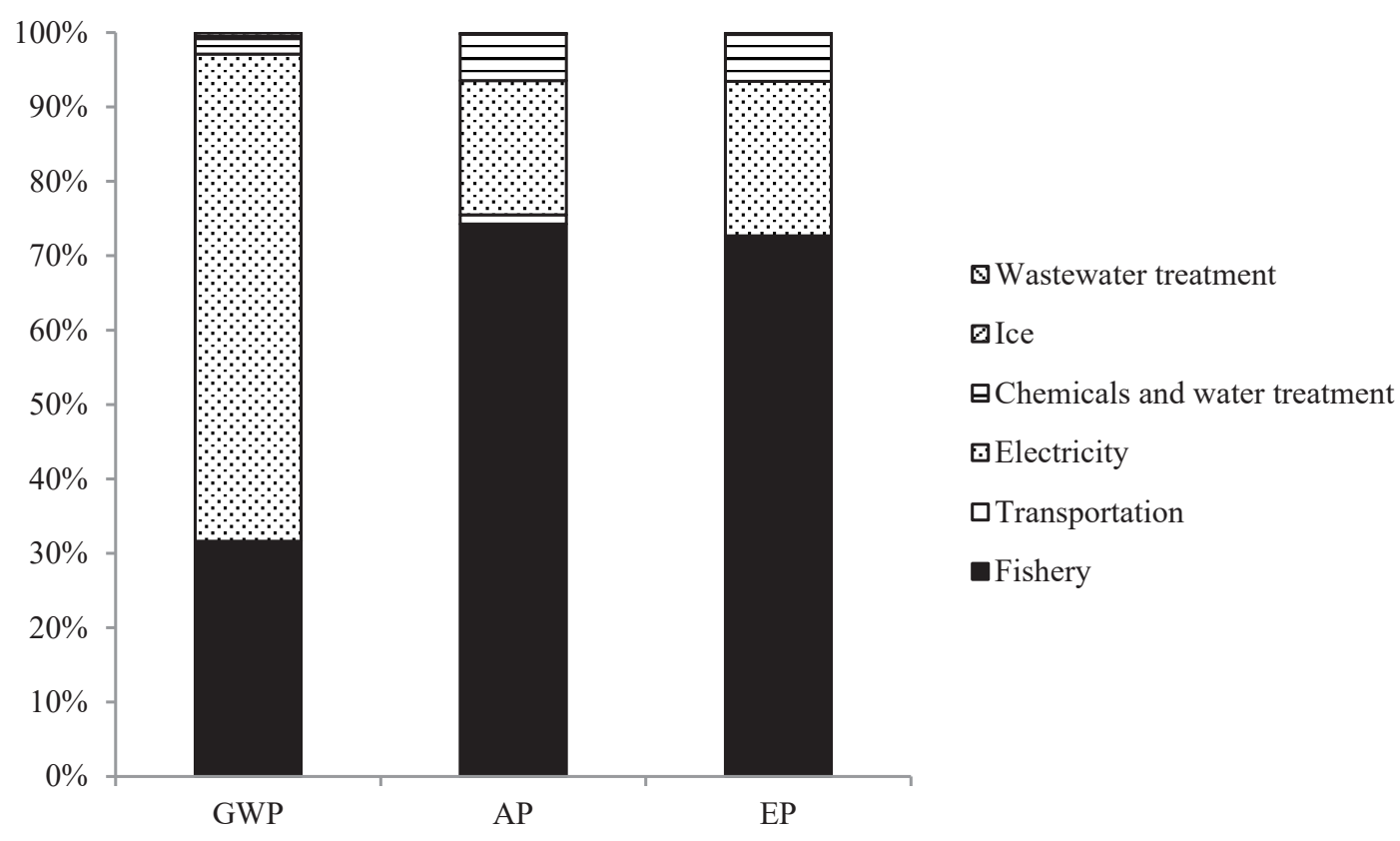


For production of ponyfish surimi (Table 6 and Fig. 4), the fish catching process resulted in $97 \%$ of the global warming potential, $97 \%$ acidification and $88 \%$ eutrophication. The underlying parameter was diesel. However, during manufacturing activities, the potential only ranged within $0.02-2.20 \%$ for the total global warming potential, $0.003-2.48 \%$ for acidification and $0.003-11.62 \%$ for eutrophication. The main contributor in this case, was the use of chemicals and water production, which are crucial to seafood processing plants for material, equipment and machine cleansing, including the production of cold water and ice. Each activity requires different types of water, such as normal room temperature water for general use but cold water for the production process. Water for general use is filtered and added with chlorine to control microbe populations. To produce soft water, salt is applied to eliminate existing resin. The use of chemicals, especially chlorine, for microbe control is maintained within the acceptable range.

Results indicated that several types of water used in manufacturing from cold to hot gave the global warming potential at $98 \%$ with $98 \%$ for acidification and $99 \%$ for eutrophication. This thorough evaluation showed that using electricity to heat water presents the greatest impact on the environment at $94 \%$ of the global warming potential.

Fig. 4. Contribution of different phases of ponyfish surimi production

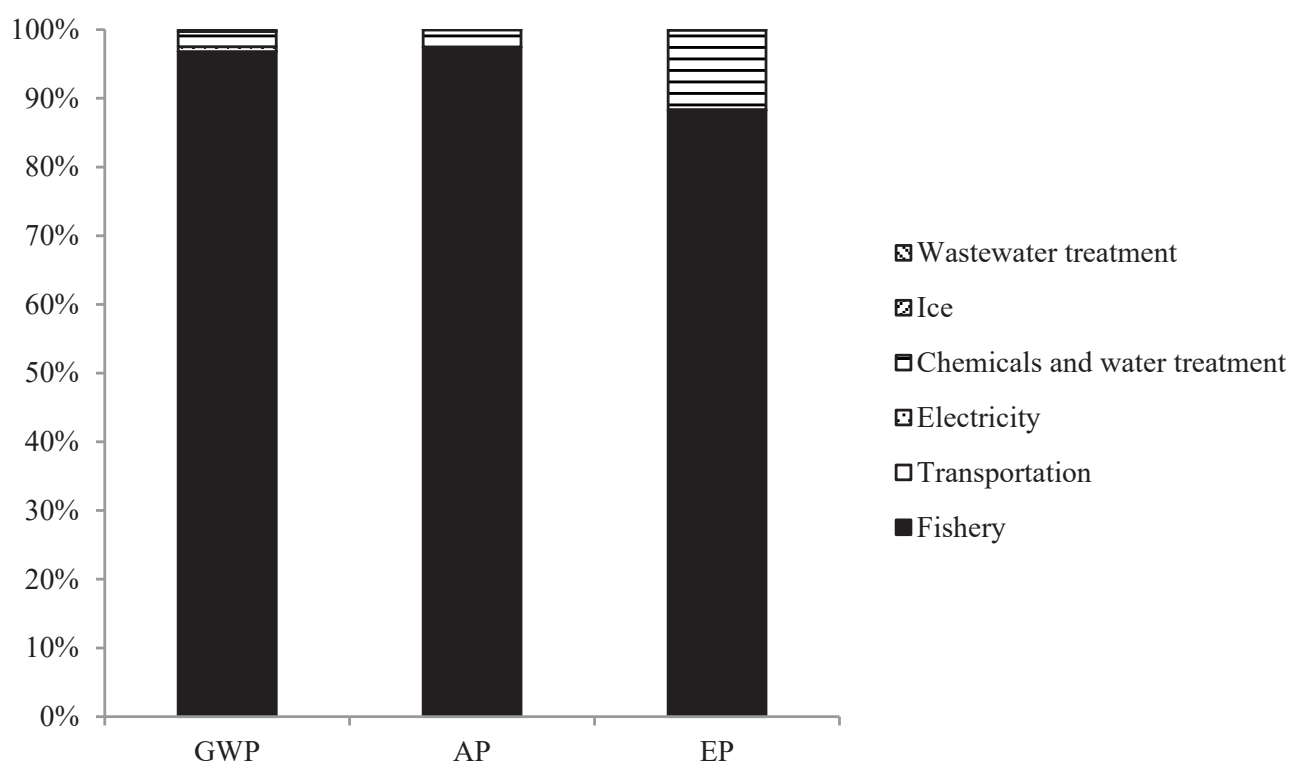

\section{Sensitivity analysis}

Life cycle impact assessment results contain several uncertain parameters; therefore, a sensitivity analysis was developed to assess the impact of variations, especially for the most significant parameters. This analysis involved calculation of different scenarios. From the results described earlier, fuel used during the fishery phase, allocation method, yield of product and electricity were determined as the most important contributors to the outcome and these parameters were set as scenarios for the sensitivity analysis.

\section{Fuel use}

One of the substantial parameters leading to environmental impacts was determined as the amount of diesel used during fish catching. Due to annual fuel data provided by participate company contained uncertainty, 
and previous research mentioned that the range is wide (Ziegler et al., 2016), therefore in this present work, sensitivity of fuel consumption was assumed to be $10 \%$ for scenario 1 and -10\% for scenario 2. Result of this sensitivity analysis was shown in Table 7. Change of fuel consumption by $10 \%$ is possible due to the distribution of fish in the ocean. For goatfish surimi, when compared with the base case (S1), global warming potential, acidification and eutrophication varied at 3\%,7\% and 7\%, respectively. When compared with the base case (S2), similar results were $3 \%, 7 \%$ and $7 \%$, respectively.
Emissions associated with ponyfish surimi displayed a larger potential variation because the main factor affecting impacts was the use of diesel, while the key contributor from goatfish surimi processing was electricity consumption during processing. Sensitivity analysis variation was approximately $10 \%$. Moreover, abundance of the target species is also a parameter to be considered (Ziegler et al., 2016). Over the same time period, lower abundance leads to lower catch rates (Ziegler et al., 2016) and fuel consumption fluctuates depending on season and species behaviour.

Table 7. Sensitivity analysis for fuel use change

\begin{tabular}{l|c|c|c|c|c|c|}
\hline & \multicolumn{3}{|c|}{ Goatfish surimi } & \multicolumn{3}{c}{ Ponyfish surimi } \\
\cline { 2 - 7 } & GWP & AP & EP & GWP & AP & EP \\
\hline Fuel use (+10\%): (S1) & 1373.00 & 3.49 & 0.78 & 2446.28 & 13.85 & 2.80 \\
\hline Fuel use (-10\%): (S1) & 1288.88 & 3.00 & 0.68 & 2014.92 & 11.38 & 2.29 \\
\hline Fuel use (+10\%): (S2) & 3077.41 & 7.82 & 1.76 & 7832.30 & 43.62 & 8.91 \\
\hline Fuel use (-10\%): (S2) & 2888.88 & 6.73 & 1.52 & 6451.20 & 35.70 & 7.29 \\
\hline
\end{tabular}

\section{Allocation}

According to Ayer et al. (2007), economic allocation is not the most appropriate method to determine seafood production LCA because it does not reflect biophysical flows of material and energy between inputs and outputs of the production system. However, they found that both mass allocation and economic allocation contributed to variation at every impact level. Mass allocation resulted in a lower impact potential economic allocation analysis because of discrepancies in selling price and yield quantity between fish products and fish waste. Hence, prices of fish products and fish waste as well as fish species are essential for LCA. Prices for surimi were increased or reduced by $10 \%$ and then analyzed using economic allocation as displayed in Table 8. Regardless of how the prices changed, variation on impact potential levels was only small at $1 \%$ compared with the base case (S2).

Table 8. Sensitivity analysis for economic allocation change

\begin{tabular}{|l|c|c|c|c|c|c|c|}
\hline & \multicolumn{3}{|c|}{ Goatfish surimi } & \multicolumn{4}{c}{ Ponyfish surimi } \\
\cline { 2 - 7 } & GWP & AP & EP & GWP & AP & EP \\
\hline Economic allocation (+10\%) & 3011.47 & 7.34 & 1.65 & 7205.14 & 40.01 & 8.17 \\
\hline Economic allocation (-10\%) & 2949.25 & 7.19 & 1.62 & 7065.77 & 39.24 & 8.01 \\
\hline
\end{tabular}

Unit: g per functional unit 


\section{Product yield}

Fish waste has the fish skin and tiny bones remaining after processing are usually bought for other purposes, such as to produce animal food. Some seafood processing plants operate their own animal food producing facilities. Interview sessions with ponyfish surimi entrepreneurs determined that sometimes the fish they caught were smaller than usual, resulting in less surimi yield, since it is more difficult to manually debone small fish. In other words, the acquired yield quantity also depends on the skills of the workers. Analysis results based on increasing or reducing the yield by $10 \%$ are indicated in Table 9 . For goatfish surimi, change of yield quantity contributed an impact variation of $5 \%$ in $\mathrm{S} 1$ and $1 \%$ in S2, while ponyfish surimi gave similar results at $10 \%$ in $\mathrm{S1}$ and $1 \%$ in S2. Thus, in terms of economic allocation, change of yield quantity caused minor variation in environmental impact levels. On the other hand, huge differences resulted from analysis by mass allocation.

Table 9. Sensitivity analysis for variation of yield change

\begin{tabular}{l|c|c|c|c|c|c|}
\hline & \multicolumn{3}{|c|}{ Goatfish surimi } & \multicolumn{3}{c}{ Ponyfish surimi } \\
\cline { 2 - 7 } & GWP & AP & EP & GWP & AP & EP \\
\hline Yield (+10\%): (S1) & 1397.49 & 3.41 & 0.77 & 2453.66 & 13.88 & 2.80 \\
\hline Yield (-10\%): (S1) & 1264.40 & 3.08 & 0.69 & 2007.54 & 11.35 & 2.29 \\
\hline Yield (+10\%): (S2) & 3007.84 & 7.34 & 1.65 & 7230.36 & 40.15 & 8.20 \\
\hline Yield (-10\%): (S2) & 2956.32 & 7.21 & 1.62 & 7136.74 & 39.08 & 7.98 \\
\hline
\end{tabular}

Unit: g per functional unit

\section{Electricity consumption}

Electricity is required for both manufacturing and water production. Table 10 shows electricity as a key parameter with a remarkable effect on global warming caused by goatfish surimi production. If the electricity consumption rate was increased or reduced by $10 \%$, the level of the GWP varied by $7 \%$ in terms of goatfish surimi, while ponyfish surimi showed only a slight change.

Table 10. Sensitivity analysis for electricity change

\begin{tabular}{l|c|c|c|c|c|c|c|}
\hline \multirow{2}{*}{} & \multicolumn{3}{|c|}{ Goatfish surimi } & \multicolumn{3}{c}{ Ponyfish surimi } \\
\cline { 2 - 7 } & GWP & AP & EP & GWP & AP & EP \\
\hline Electricity (+10\%): (S1) & 1419.18 & 3.61 & 0.81 & 2237.33 & 12.66 & 2.55 \\
\hline Electricity (-10\%): (S1) & 1242.71 & 3.03 & 0.68 & 2223.87 & 12.54 & 2.52 \\
\hline Electricity (+10\%): (S2) & 3180.92 & 7.76 & 1.74 & 7163.30 & 39.74 & 8.08 \\
\hline Electricity (-10\%): (S2) & 2785.37 & 6.78 & 1.52 & 7120.20 & 39.01 & 7.86 \\
\hline
\end{tabular}

\section{Summary}

Sensitivity analysis was conducted for four parameters: fuel used in the fishery phase, economic allocation in surimi processing, yield of fish in surimi processing, and electricity use. During processing of goatfish surimi, changes in parameters caused variation of the global warming potential at 3-7\% with change in electricity use delivering the most outstanding variation (6.6\%). Changes in diesel usage during the fishing phase gave the least effect on the result 
(3.1\%). For ponyfish surimi, variation was identified at $0.3-10 \%$. The use of electricity during processing resulted in the least variation to the GWP $(0.3 \%)$, while change in yields delivered the greatest effect on the GWP in scenario 1 (10\%) with change in diesel consumption showing the highest effect in scenario 2 (9.7\%). Meanwhile, the impact on AP and EP was in the same way as the GWP.

\section{Conclusions}

Considerable options exist for improvements regarding the environmental impacts of Thai surimi production and its supply chain. This environmental assessment for surimi produced in Southern Thailand resulted in global warming of $1.33-7.14 \mathrm{~kg} \mathrm{CO}_{2}$ eq per $\mathrm{kg}$ surimi. Acidification and eutrophication were calculated at $3.29-39.66 \mathrm{~g} \mathrm{SO}_{2}$ eq per $\mathrm{kg}$ surimi and $0.75-8.10 \mathrm{~g} \mathrm{PO}_{4}$ eq per $\mathrm{kg}$ surimi, respectively. In the fishery industry, the most important environmental measure concerns the amount of fuel used and electricity consumption, with the main contributions to the GWP. Four sensitivity analysis scenarios were conducted. The results showed that changes in electricity use, fuel use and yield were the most influential factors depending on each scenario. Derived life cycle assessment methodology can benefit both companies and policy-makers to improve the sustainability of processes and products. To have a more sustainable improvement, some indicators might be selected to monitor, such as fuel use per landing in fishery and electricity consumption per production in surimi processing. Improving fishery methodology and fishing gears will lead to increasing in both environmental and economic performance. For policy-makers, results of this life cycle assessment can be utilized to identify and rectify hotspots in the supply chain. For example, increasing renewable energy sources could be considered in national power plant policy and planning.

\{Gurauskiene, 2006, Eco-design methodology for electrical and electronic equipment industry\}

\section{References}

Arvanitoyannis I.S. and Kassaveti A. (2008) Fish Industry Waste: Treatments, Environmental Impacts, Current and Potential Uses. International Journal of Food Science and Technologies 43(4): 726-745. https://doi.org/10.1111/j.1365-2621.2006.01513.x

Aubin J., Papatryphon E., van der Werf H.M.G. and Chatzifotis S. (2009) Assessment of the Environmental Impact of Carnivorous Finfish Production System using Life Cycle Assessment. Journal of Cleaner Production 17(3): 354-361. https://doi. org/10.1016/j.jclepro.2008.08.008

Avadi A. and Freon P. (2013) Life Cycle Assessment of Fisheries: A Review for Fisheries Scientists and Managers. Fisheries Research 143: 21-38. https://doi.org/10.1016/j.fishres.2013.01.006

Ayer N.W., Tyedmers P.H., Pelletier N.L., Sonesson U. and Scholz A. (2007) Co-Product Allocation in Life Cycle Assessment of Seafood Production Systems: Review of Problems and Strategies. International Journal of Life Cycle Assessment 12(7): 480-487. https://doi.org/10.1065/lca2006.11.284

Department of Fisheries (2016). Statistics of Fisheries Factory 2014, Thailand, No. 11/2016. Available at: http://www1.fisheries.go.th/it-stat/images/stories/yearbook/yearbook2557.pdf (accessed 6 June 2018).
Ellingsen H. and Aanondsen S.D. (2006) Environmental Impacts of Wild Caught Cod and Farmed Salmon-A Comparison with Chicken. International Journal of Life Cycle Assessment 11(1): 60-65. https://doi.org/10.1065/lca2006.01.236

Ferraciolli L., Luiz D. and Naval L.P. (2017) Potential for Reuse of Effluent from Fish Processing Industries. Revista Ambiente \& Aqua 12(5): 730-742. https://doi.org/10.4136/ambi-agua.2045

FAO (Food and Agriculture Organization of the United Nations) (2016) FAO yearbook: Fishery and Aquaculture Statistics 2016 , Rome, Italy.

Garnett T. (2011) Where are the best opportunities for reducing greenhouse gas emissions in the food system (including the food chain)?. Food Policy 36: 523-532. https://doi. org/10.1016/j.foodpol.2010.10.010

Guinee J.B., Gorree M., Heijungs R., Huppes G., Kleijn R., de Koning A., van Oers L., Wegener A., Suh S. and Udo de Haes H.A. (2001) Life Cycle Assessment-An Operational Guide to the ISO Standards. Leiden: Centre of Environmental Science.

Guenneugues P. and lanelli J. (2014) Surimi resources and market. In: Surimi and Surimi Seafood, 3rd edition, Park, J.W. (ed.), CRC Press, Boca Raton, FL: 25-53. https://doi.org/10.1201/ b16009-4 
Henriksson P.J.G., Guinee J.B., Kleijn R. and de Snoo G.R. (2012) Life Cycle Assessment of Aquaculture Systems-a Review of Methodologies. International Journal of Life Cycle Assessment 17(3): 304-313. https://doi.org/10.1007/s11367-011-0369-4

Hornborg S., Nilsson P., Valentinsson D. and Ziegler F. (2012) Integrated environmental assessment of fisheries management: Swedish Nephrops trawl fisheries evaluated using a life cycle approach, Marine Policy 36: 1193-1201. https://doi. org/10.1016/j.marpol.2012.02.017

Hospido A., Vazques M.E., Cuevas A., Feijoo G. and Moreira M.T. (2006) Environmental Assessment of Canned Tuna Manufacture with a Life-Cycle Perspective. Resources, Conservation and Recycling 47(1): 56-72. https://doi.org/10.1016/j.resconrec.2005.10.003

Hyun-young K., Yong-su Y. and Bo-kyu H. (2017) A quantitative analysis of greenhouse gas emissions from the major coastal fisheries using the LCA method. Journal of the Korean Society of Fisheries and Ocean Technology 53(1): 77-88. https://doi. org/10.3796/KSFT.2017.53.1.077

ISO (International Standards Organization) (2006) Environmental Management-Life Cycle Assessment-Principles and Framework, IS014040, BSI, CEN.

Iribarren D., Moreira M.T. and Feijoo G., (2010) Life cycle assessment of fresh and canned mussel processing and consumption in Galicia (NW Spain). Resources, Conservation and Recycling 55: 106-117. https://doi.org/10.1016/j.resconrec.2010.08.001

Iribarren D., Vazques-Rowe I., Hospido A., Moreira M.T. and Feijoo G. (2011) Estimation of the Carbon Footprint of the Galician Fishing Activity (NW Spain). Science of Total Environment 409: 1609-1611. https://doi.org/10.1016/j.scitotenv.2011.01.007

Jaehyun B., Yong-su Y., Hyun-young K., Bo-kyu H. and Chunwoo L. (2019), A quantitative analysis of greenhouse gas emissions from the major offshore fisheries. Journal of the Korean Society of Fisheries and Ocean Technology 55(1): 50-61. https:// doi.org/10.3796/KSFOT.2019.55.1.050

Kaewudom P., Benjakul S. and Kijroongrojana K. (2013) Properties of Surimi Gel as Influenced by Fish Gelatin and Microbial Transglutaminase. Food Bioscience 1: 39-47. https://doi. org/10.1016/j.fbio.2013.03.001

Laso J., Vazquez-Rowe I., Margallo M., Crujeiras R.M., Irabien A. and Aldaco R. (2018) Life cycle assessment of Europena anchovy (Engraulis encrasicolus) landed by purse seine vessels in northern Spain. International Journal of Life Cycle Assessment 23: 1107-1125. https://doi.org/10.1007/s11367-017-1318-7

Morrissey M.T. and Tan S.M. (2000) World Resources for Surimi, In J.W. Park (ed.), Surimi and surimi seafood, New York, USA, Marcel Dekker: 1-21.
Parker R. (2012) Review of Life Cycle Assessment Research on Products Derived from Fisheries and Aquaculture: A Report for Seafish as Part of the Collective Action to Address Greenhouse Gas Emissions in Seafood. Sea Fish Industry Authority, Edinburgh, UK.

Parker R. and Tyedmers P.H. (2012) Uncertainty and Natural Variability in the Ecological Footprint of Fisheries: A Case Study of Reduction Fisheries for Meal and Oil. Ecological Indicators 16: 76-83. https://doi.org/10.1016/j.ecolind.2011.06.015

Pelletier N. and Tyedmers P. (2008) Life Cycle Considerations for Improving Sustainability Assessments in Seafood Awareness Campaigns. Environmental Management 42(5): 918-931. https://doi.org/10.1007/s00267-008-9148-9

Reckmann K., Traulsen I. and Krieter J. (2012) Environmental Impact Assessment-Methodology with Special Emphasis on European Pork Production. Environmental Management 107: 102-109. https://doi.org/10.1016/j.jenvman.2012.04.015

Rebitzer G., Ekavall T., Frischknecht R., Hunkeler D., Norris G., Rydberg T. Schmidt W.P., Suh S., Weidema B.P. and Pennington D.W. (2004) Life Cycle Assessment Part 1: Framework, Goal and Scope Definition, Inventory Analysis and Applications. Environment International 30(5): 701-720. https://doi.org/10.1016/j. envint.2003.11.005

Rehl T., Lansche J. and Muller J. (2012) Life Cycle Assessment of Energy Generation form Biogas-Attributional vs Consequential Approach. Renewable and Sustainable Energy Reviews 16(6): 3766-3775. https://doi.org/10.1016/j.rser.2012.02.072

Shaviklo A.R. and Rafipour F. (2013) Surimi and Surimi Seafood From Whole Ungutted Myctophid Mince. LWT-Food Science and Technology 54(2): 463-468. https://doi.org/10.1016/j. Iwt.2013.06.019

Svanes E., Vold M. and Hanssen O.J. (2011a) Effect of Different Allocation Method on LCA Results of Products from Wild-Caught Fish and on the Use of Such Results. International Journal of Life Cycle Assessment 16(6): 512-521. https://doi.org/10.1007/s11367-011-0288-4

Svanes E., Vold M. and Hanssen O.J. (2011b) Environmental Assessment of Cod (Gadus Morhua) from Autoline Fisheries. International Journal of Life Cycle Assessment 16(7): 611-624. https://doi.org/10.1007/s11367-011-0298-2

Thrane M. (2006) LCA of Danish Fish Product. New Methods and Insights. International Journal of Life Cycle Assessment 11(1): 66-74. https://doi.org/10.1065/lca2006.01.232

Thrane M., Nielsen E.H. and Christensen P. (2009) Cleaner Production in Danish Fish Processing-Experiences, Status and Possible Future Strategies. Journal of Cleaner Production 17(3): 380-390. https://doi.org/10.1016/j.jclepro.2008.08.006 
Vazques-Rowe I., Moreira M.T. and Feijoo G. (2010) Life Cycle Assessment of House Mackerel Fisheries in Galicia (NW Spain): Comparative Analysis of Two Major Fishing Methods. Fisheries Research 106(3): 517-527. https://doi.org/10.1016/j.fishres.2010.09.027

Vazques-Rowe I., Moreira M.T. and Feijoo, G. (2012) Environmental Assessment of Frozen Common Octopus (Octopus Vulgaris) Captured by Spanish Fishing Vessels in the Mauritanian EEZ. Marine Policy 36(1): 180-188. https://doi.org/10.1016/j. marpol.2011.05.002

Weidema B.P., Thrane M., Christensen P., Schmidt J. and Lokke S. (2008) Carbon Footprint. A Catalyst for Life Cycle Assessment?. Journal of Industrial Ecology 12(1): 3-6. https://doi. org/10.1111/j.1530-9290.2008.00005.x

Ziegler F., Emanuelsson A., Eichelsheim J.L., Flysjo A., Ndiaye V. and Thrane M. (2011) Extended Life Cycle Assessment of Southern Pink Shrimp Products Originating in Senegalese Artisanal and Industrial Fisheries for Export to Europe. Journal of
Industrial Ecology 15: 527-538. https://doi.org/10.1111/j.15309290.2011.00344.x

Ziegler F., Hornborg S., Green B.S., Eigaard O.R., Farmery A.K., Hammar L., Haartmann K., Molander S., Parker R.W.R., Hognes E.S., Vazquez-Rowa I. and Smith A.D.M. (2016) Expanding the concept of sustainable seafood using life cycle assessment, Fish and Fisheries 17: 1073-1093. https://doi.org/10.1111/ faf.12159

Ziegler F., Nilsson P., Mattsson B. and Walther Y. (2003) Life Cycle Assessment of Frozen Cod Fillers including Fishery-Specific Environmental Impacts. International Journal of Life Cycle Assessment 8: 39-47. https://doi.org/10.1007/BF02978747

Ziegler F., Groen E.A., Hornborg S., Bokkers E.A.M., Karlsen K.M. and de Boer I.J.M. (2018) Assessing broad life cycle impacts of daily onboard decision-making, annual strategic planning, and fisheries management in a northeast Atlantic trawl fishery. International Journal of Life Cycle Assessment 23: 1357-1367. https://doi.org/10.1007/s11367-015-0898-3 